\title{
EFFECT OF GUIDED DEEP BREATH RELAXATION AND KEGEL GYM ON PERINEAL PAIN REDUCTION IN POSTPARTUM WOMEN AT BULELENG HOSPITAL, BALI
}

\author{
Luh Ayu Purnami'1), R. Soerjo Hadijono²), Lucky Herawati3) \\ ${ }^{1)}$ School of Health Sciences Buleleng \\ 2)School of Health Sciences Guna Bangsa Yogyakarta \\ 3)School of Health Polytechnics, Ministry of Health Yogyakarta
}

\begin{abstract}
Background: Mothers regardless of their ethnicity and demographic characters described post-partum pain as one of the serious problem after giving births. Severe perineal pain can distract the mother and therefore interrupt the initial bonding process between mother and baby which is very essential. Deep breathing helps relax the body and mind. Learning deep breathing reduces muscle tension thereby lessening pain. This study aimed to analyze the effect of guided deep breath relaxation and Kegel gym on perineal pain reduction in postpartum women at Buleleng Hospital, Bali.

Subjects and Method: This study was a quasi experiment with a pre-test and post-test with control group design. It was conducted at Buleleng hospital, Bali. A total of 82 postpartum mothers was divided into 2 groups: 41 postpartum mothers in experimental group and 41 postpartum mothers in control group. The independent variable was Kegel gym and guided deep breathing. The dependent variable was perineal pain at 12 hours, 24 hours, and 48 hours. The data were collected using a pain observation sheet in the form of a Numeric Rating Scale (NRS), Standard Operating Procedure (SOP), and leaflets on guided deep breath that had been developed by researchers. The data were analyzed using Paired t-test and Independent Test t-test and Manova test.

Results: Decrease in perineal pain in the experimental group (Mean= 2.78) was larger than the control group (Mean=1.52), and it was statisticallly significant.

Conclusion: The guided deep breathing method is more effective in reducing maternal perineal pain at 24 hours postpartum. It is expected that guided deep breathing can be used as an alternative method of overcoming persistent perineal pain.
\end{abstract}

Keywords: guided deep breath, Kegel exercise, pain, perineum, postpartum

\section{Correspondence:}

Luh Ayu Purnami. School of Health Sciences Buleleng, Jl. Raya Air Sanih KM 11 Bungkulan Singaraja, Buleleng, Bali. Email: ayupurnami40@gmail.com. Mobile: 087863069849 . 